\title{
Model Pembelajaran Student Facilitator and Explaining dalam Meningkatkan Motivasi dan Hasil Belajar Al-Qur'an Hadits Siswa Madrasah Ibtidaiyah
}

\author{
Agri Bastiar ${ }^{1}$, Raehang ${ }^{2}$, H. Pairin' ${ }^{2}$, \\ 1 Institut Agama Islam Negeri (IAIN) Kendari. E-mail: agribastiar42@gmail.com \\ 2 Institut Agama Islam Negeri Kendari, Indonesia. E-mail: asyrafraehang@gmail.com \\ 2 Institut Agama Islam Negeri Kendari, Indonesia. E-mail: pairinma@yahoo.co.id
}

\section{Articel info}

Artikel history:

Received: 12 -10-2020

Revised : 28 -12- 2020

Accepted: 10 -02- 2021

\section{Keywords:}

Keywords satu;

Keywords dua;

Keywords tiga;

\begin{abstract}
This study aims to increase motivation and learning outcomes of students in the Qur'an Hadith at MIN 1 Kendari through the implementation of the Student Facilitator And Explaining learning model. This is a classroom action research. The research subjects were students of class $V B$ MIN 1 Kendari with 27 students. The research procedure includes planning, implementation, observation, evaluation and reflection. Data collection techniques used observations, tests, questionnaires, and documentation which were analyzed descriptively qualitatively. The results showed that the use of the Student Facilitator and Explaining learning model could increase the learning motivation of students at MIN 1 Kendari with the presentation of student learning motivation reaching $88.88 \%$ with very high category. There was also an increase in student learning outcomes after the implementation of the Student Facilitator And Explaining learning model with a good percentage of student learning outcomes of $81.48 \%$.
\end{abstract}

Penelitian ini bertujuan meningkatkan motivasi dan hasil belajar al-Qur'an Hadits siswa MIN 1 Kendari melalui penerapan Model pembelajaran Student Facilitator And Explaining. Penelitian adalah penelitian tindakan kelas. Subjek penelitian adalah siswa kelas V B MIN 1 Kendari berjumlah 27 siswa. Prosedur penelitian meliputi perencanaan, pelaksanaan, observasi, evaluasi dan refleksi. Teknik pengumpulan data menggunakan observasi, tes, angket, dan dokumentasi yang dianalisis secara deskriptif kualitatif. Hasil penelitian menunjukan bahwa penerapan model pembelajaran Student Facilitator And Explaining dapat meningkatkan Motivasi belajar siswa MIN 1 Kendari dengan persentase motivasi belajar siswa mencapai 88,88\% kategori sangat tinggi. Terjadi pula peningkatan hasil belajar siswa setalah diterapkannya model pembelajaran Student Facilitator and Explaining dengan persentase ketuntasan hasil belajar siswa yang sudah baik sebesar $81,48 \%$.

\section{PENDAHULUAN}

Pendidikan merupakan hal yang sangat penting dalam membangun peradaban bangsa. Pendidikan merupakan salah satu aset untuk membangun sumber daya manusia yang berkualitas. Lewat pendidikan bermutu, bangsa dan negara akan terjunjung tinggi martabat dimata dunia"(Aris Shoimin, 
2013.h.20). Sebagai seorang pendidik harus mampu memberikan dorongan yang positif sehingga siswa dapat termotivasi dalam mengikuti proses pembelajaran serta menciptakan suasana belajar yang menyenangkan agar siswa bisa berkembang semaksimal mungkin. Hal ini sesuai dengan fungsi dan tujuan pendidikan yang terdapat dalam Undang-Undang RI No. 20 Tahun 2003 pada BAB II pasal 3 yakni pendidikan nasional berfungsi mengembangkan kemampuan dan membentuk watak serta peradaban bangsa yang bermartabat dalam rangka mencerdaskan kehidupan bangsa, bertujuan untuk mengembangkan potensi siswa agar menjadi manusia yang beriman dan bertakwa kepada Tuhan Yang Maha Esa, berakhlak mulia, sehat, berlimu, cakap, kreatif, mandiri dan menjadi warga Negara yang demokratis dan bertanggung jawab.(UU RI N0.20 Tahun 2003,h.8).

Sistem pendidikan nasional memiliki fungsi untuk mencerdaskan kehidupan bangsa Indonesia dan untuk menciptakan masyarakat Indonesia yang beradab dan berakhlak mulia. Selain itu, pendidikan juga dapat mendorong peningkatan kualitas manusia dalam meningkatkan kompetensi kognitif, afekif maupun psikomotorik melalui kemampuan yang telah dimilikinya. Inovasi pembelajaran merupakan suatu hal yang sangat perlu dilakukan oleh seorang guru atau pendidik. Dengan adanya inovasi pembelajaran yang dilakukan oleh guru atau pendidik maka akan menghasilkan suatu proses pembelajaran yang lebih bermakna dan berkesan pada diri siswa.

Proses pembelajaran dalam dunia pendidikan secara umum melibatkan empat buah komponen utama yaitu: siswa, guru, lingkungan belajar dan materi pelajaran. Keempat komponen ini mempengaruhi siswa dalam mencapai tujuan belajar. Setiap siswa mempunyai tingkat kemampuan yang berbeda-beda jika dilihat dari daya tangkap terhadap pelajaran, pengetahuan yang dimilikinya dalam bidang yang dipelajari, keterampilan belajar, tujuan belajar dan lain-lain. Guru harus membimbing siswa dan memberikan motivasi agar dapat mengembangkan pengetahuannya sesuai dengan bidang studi yang dipelajari.peran kemauan dan motivasi dalam belajar sangat penting dalam memulai dan memelihara usaha siswa. Disini penulis mencoba untuk melakukan penelitian tentang salah satu model pembelajaran yang dilakukan di kelas VB pada pembelajaran Al-Qur'an Hadits yang disebut dengan model pembelajaran Student facilitator and explaining (SFAE).

Pada observasi awal yang dilakukan oleh peneliti, peneliti menemukan beberapa permasalahan dalam proses pembelajaran Al-Qur'an Hadits yang dilakukan oleh guru mata di MIN 1 Kendari. Dalam melaksanakan proses pembelajaran, guru mata pelajaran Al-Qur'an Hadits di MIN I Kendari masih menggunakan model pembelajaran konvensional dan cenderung monoton dalam menyampaikan materi pembelajaran sehingga banyak siswa yang kurang bersemangat dalam mengikuti proses pembelajaran. Hasil wawancara dengan salah satu guru mata pelajaran Al-Qur'an Hadits di MIN 1 Kendari mengungkapkan bahwa kesulitan dalam mencari model yang cocok untuk mata pelajaran AlQuran Hadits adalah alasan tidak digunakannya model-model pembelajaran yang baru dalam melaksanakan pembelajaran. Lebih lanjut keterangan dari salah satu siswa kelas V terungkap bahwa siswa merasa bosan dan tidak bersemangat saat mengikuti pembelajaan Al-Qur'an Hadits karena kebanyakan kegiatan yang dilakukan adalah menulis dan menghafal. Dan tentunya fenomena tersebut berdampak negatif terhadap rendahnya hasil belajar siswa. Dari 27 siswa yang mengikuti proses pembelajaran, hanya sebanyak 13 siswa yang mencapai kategori tuntas. Data hasil test belajar siswa dapat dilihat pada tabel 1.

Mengamati fenomena tersebut tentunya dibutuhkan suatu tindakan untuk mengatasi masalah yang terjadi di lapangan. Salah satu alternatif yang dapat digunakan dalam meningkatkan motivasi dan hasil belajar siswa adalah diterapkannya model pembelajaran Student Facilitator and Explaining. Model pembelajaran Student Facilitator and Explaining merupakan salah satu tipe pembelajaran kooperatif yang menekankan pada struktur khusus yang dirancang untuk merangsang mental siswa dalam menyampaikan pemahaman mereka tentang materi pembelajaran kepada teman kelasnya dan memiliki tujuan untuk meningkatkan penguasaan materi. La Anse \& Ilham (2018:2) menyatakan 
pembelajaran kooperatif merupakan salah satu model pembelajaran yang melibatkan siswa dalam group kecil dan hetergon yang bekerja dengan saling mendukung satu sama lainnya untuk memaksimalkan pemahaman terhadap hasil belajar. Hasil Penelitian Aziz, dkk. dengan judul "Penerapan Model Pembelajaran Student Facilitator and Explaining untuk Meningkatkan Minat dan Motivasi Belajar Fisika Siswa Kelas X SMA Negeri 10 Purworejo Tahun Ajaran 2013/2014" menunjukan peningkatan motivasi dan minat belajar fisika di kelas X SMA Negeri 10 Purworejo setelah diterapkannya metode pembelajaran tersebut.

\section{Tabel 1. Data hasil belajar siswa sebelum dilakukan tindakan}

\begin{tabular}{lc}
\hline Jumlah Siswa & 27 \\
Nilai Rata-Rata & 71,85 \\
Jumlah Siswa Tuntas & 13 \\
Jumlah Siswa Tidak Tuntas & 14 \\
Presentase Ketuntasan & $48,14 \%$ \\
Presentase ketidak tuntasan & $51,85 \%$ \\
\hline
\end{tabular}

\section{METODE}

Jenis penelitian ini adalah penelitian tindakan kelas (classroom action research). Penelitian ini dilakukan dalam 2 (dua) siklus, dimana masing-masing siklus terdiri dari perencanaan, pelaksanaan tindakan, pengamatan atau observasi serta refleksi. Penelitian ini dilaksanakan di semester genap tahun ajaran 2019/2020 di kelas V B di MIN 1 Kendari selama dua bulan Pada bulan Januari sampai bulan Februari tahun 2020. Populasi dalam penelitian ini adalah siswa kelas V di MIN 1 Kendari. Sedangkan sampel penelitian dalam penelitian ini adalah siswa kelas V B MIN 1 Kendari yang berjumlah 27 siswa. Teknik pengumpulan data dalam penelitian ini dilakukan yaitu observasi, angket, tes, dan dokumentasi. Indikator ketuntasan hasil belajar pada MIN I Kendari adalah nilai siswa lebih dari 75. Sedangkan ketuntasan secara klasikal yaitu 80\% siswa telah mencapai nilai KKM.

Pedoman Penilaian Angket Motivasi Belajar

\begin{tabular}{ccc}
\hline & & Skor \\
\cline { 2 - 3 } Kriteria & Positif & Negativ \\
\hline Sangat setuju & 4 & 1 \\
Setuju & 3 & 2 \\
Tidak setuju & 2 & 3 \\
Sangat tidak setuju & 1 & 4 \\
\hline
\end{tabular}

diadaptasi dari sugiyono (2009: 94)

Jenjang kriteria hasil angket motivasi belajar

\begin{tabular}{ccc}
\hline No. & Persentase & Kualifikasi \\
\hline 1. & $75,01 \%-100 \%$ & Sangat tinggi \\
2. & $51,01 \%-75 \%$ & Tinggi \\
3. & $25,01 \%-50 \%$ & Sedang \\
4. & $0 \%-25 \%$ & Rendah \\
\hline
\end{tabular}

diadaptasi dari sugiyono (2009: 94)

Dalam menentukan nilai rata-rata perolehan hasil belajar menggunakan rumus: $x=\frac{\sum f}{N}$ 
Keterangan :

$\mathrm{X}-\quad=$ Jumlah nilai rata-rata yang diperoleh siswa

$\sum \mathrm{f} \quad=$ jumlah nilai yang dperoleh setiap siswa

$\mathrm{N} \quad=$ jumlah seluruh siswa dalam kelas (Sudijono, 2004)

Untuk menentukan ketuntasan hasil belajar siswa menggunakan rumus $\mathrm{P}=\frac{\Sigma f i}{N} \times 100 \%$

Keterangan :

$\mathrm{P} \quad=$ presentase ketuntasan

$\sum f i=$ jumlah siswa pada kategori ketuntasan belajar

$\mathrm{N} \quad=$ jumlah siswa secara keseluruhan (Supardi, 2006)

Untuk menentukan peningkatan hasil belajar menggunakan rumus $\mathrm{P}=\frac{\text { postrate-baserate }}{\text { baserate }} \times 100 \%$

Keterangan:

$\mathrm{P} \quad=$ presentase penigkatan

Postrate $=$ Nilai sesudah tindakan

Baserate $=$ Nilai sebelum tindakan (Aqib, 2001)

Menentukan nilai pada lembar observasi siswa dan guru

$$
\text { Nilai perolehan }=\frac{\text { skor } \text { perolehan }}{\text { skor maksimal }} \times 100 \%
$$

(Aqib, 2011)

\section{HASIL DAN PEMBAHASAN}

\section{HASIL PENELITIAN}

\section{Motivasi Belajar Siswa}

Sebelum dilakukan tindakan, 19 siswa menunjukkan motivasi belajar dalam kategori baik tetapi terdapat 8 siswa dalam kategori kurang baik. Persentase keberhasilan motivasi belajar mencapai $70,37 \%$. Pada tindakan siklus I persentase angket motivasi belajar sebesar $85,19 \%$ tergolong dalam kategori sangat tinggi. Hal ini menunjukkan bahwa terjadi peningkatan motivasi belajar siswa setelah diterapkannya model pembelajaran Student Facilitator and Explaining dengan persentase peningkatan sebesar 14,82\%. Kemudian pada Tindakan siklus II, motivasi siswa dalam kategori baik mencapai 25 siswa dengan persentase $88,88 \%$ dan sisanya masih dalam kategori kurang baik. Peningkatan motivasi belajar siswa dari pra siklus ke siklus II sebesar 18,51\% dan dari siklus I ke siklus II sebesar 3,69\%, dimana meningkat dari kategori cukup termotivasi menjadi sangat termotivasi. Bagan Peningkatan Motivasi Belajar Siswa dapat dilihat pada gambar 1.

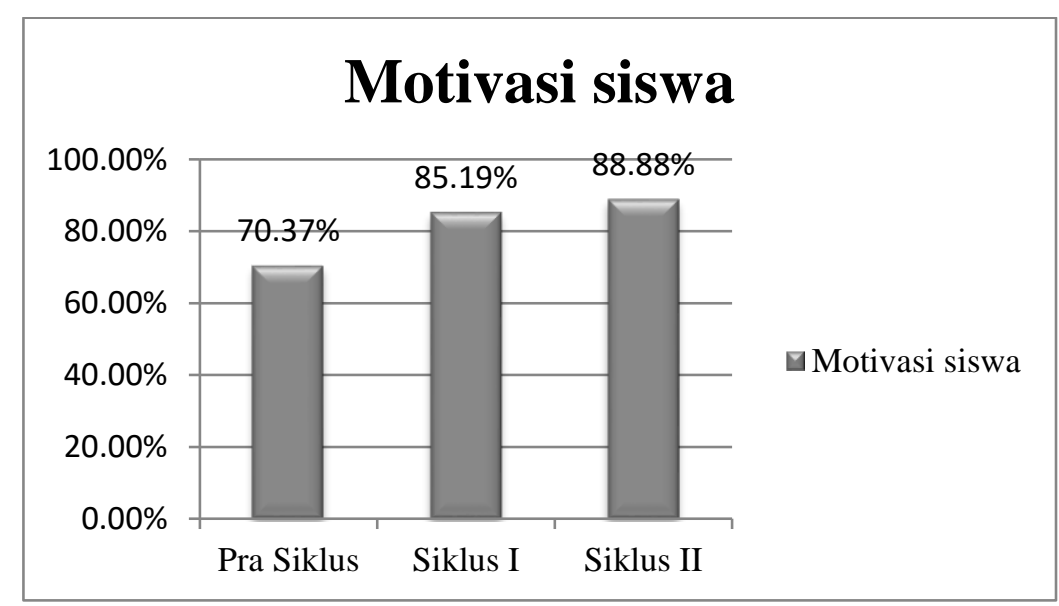

Gambar 1. Peningkatan motivasi siswa dari tiap siklus 


\section{Hasil Belajar Siswa}

Data hasil belajar dari 27 siswa sebelum dilakukan tindakan menunjukkan hanya 13 siswa yang telah mencapai KKM dengan persentase ketuntasan sebesar 48,14\%. Hal ini menunjukan bahwa siswa masih belum mengusai materi yang diajarkan dengan maksimal. Setelah dilakukan tindakan silkus I melalui penerapan model pembelajaran student Facilitator and explaining, terdapat 15 siswa yang mencapai nilai KKM (nilai $\geq 75$ ) namun jumlah siswa yang tidak mencapai KKM sebanyak 12 siswa. Ketuntasan secara klasikal pada siklus I mencapai 55,55\% dengan rata-rata 75,92. Peningkatan hasil belajar siswa dari pra siklus ke siklus I adalah sebesar 15,39\%. Pada Tindakan siklus II, jumlah siswa yang mencapai nilai KKM mengalami peningkatan yaitu menjadi 22 siswa dan yang tidak tuntas sebanyak 5 siswa. Dari kelima siswa yang tidak tuntas tersebut 2 diantaranya tidak hadir dan 3 nilainya tidak mencapai KKM yang ditentukan oleh sekolah. Persentase ketuntasan hasil belajar mencapai $81,48 \%$.

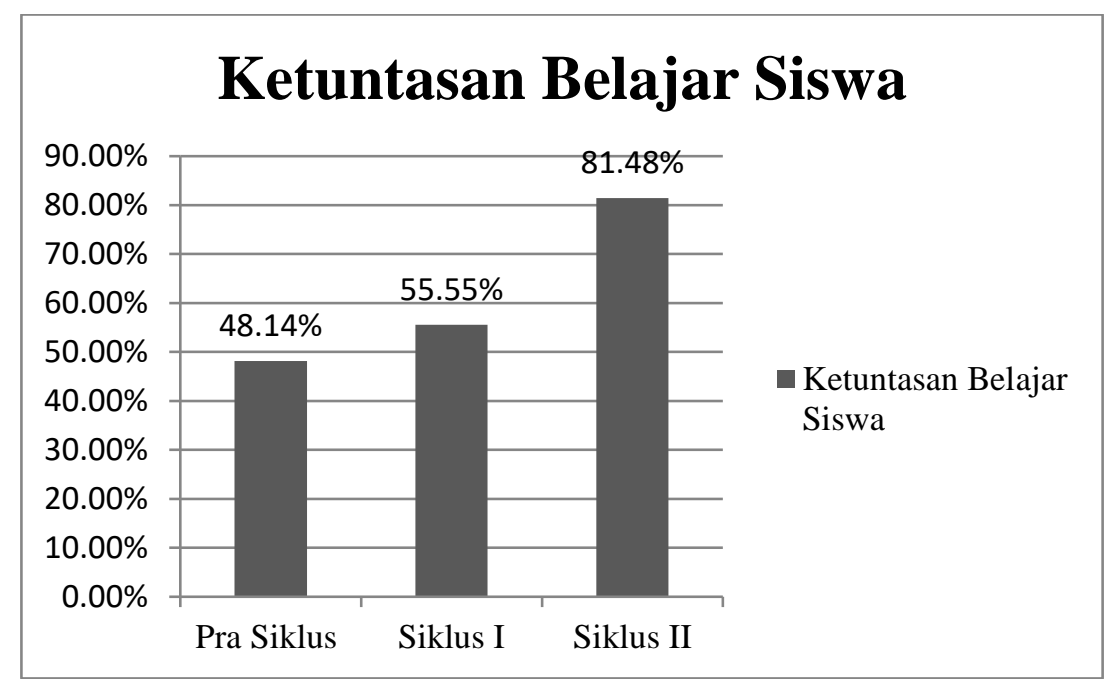

Gambar 2. Peningkatan ketuntasan belajar siswa dari tiap siklus

\section{PEMBAHASAN}

\section{Motivasi Belajar Siswa}

Pelaksanaan tindakan dimulai pada siklus I yang dilaksanakan sebanyak dua kali pertemuan. Pada setiap pertemuan, guru melakukan proses pembelajaran sesuai dengan sintaks atau langkah-langkah dari model pembelajaran Student Facilitator and Explaining. Untuk pemberian angket motivasi belajar siswa diberikan di akhir pembelajaran pertemuan kedua. Pemberian angket motivasi belajar ini diberikan dengan tujuan untuk mengetahui sejauh mana penigkatan motivasi belajar siswa selama proses pelaksanaan pembelajaran melalui penerapan model pembelajaran Student Facilitator and explaining. Adapun hasil angket motivasi belajar siklus I memperoleh persentase $85,19 \%$ tergolong kedalam kategori motivasi belajar sangat tinggi dengan rata-rata 86,51 dengan jumlah siswa sebanyak 27 orang. Hasil angket motivasi belajar siswa ini membuktikan bahwa model pembelajaran Student Facilitator and explaining dapat meningkatkan motivasi belajar siswa. Pelaksanaan tindakan Siklus II, dilakukan sebanyak dua kali pertemuan. Untuk pemberian angket motivasi belajar siswa diberikan pada siklus II pertemuan kedua di akhir pembelajaran melalui penerapan model pembelajaran Student Facilitator and explaining. Adapun hasil angket motivasi belajar siswa pada siklus I memperolah persentase sebesar $88,88 \%$ tergolong dalam kategori sangat tinggi dengan rata-rata 89,29\%. Hasil tersebut didukung dengan penelitian Rully Marcalina (2014) bahwa penerapan model pembelajaran Student Facilitator and Explaining(SFAE) dapat meningkatkan Motivasi belajar siswa SMP Negeri 1 
Mojotegah tahun ajaran 2013/2014.

Berdasarkan uraian diatas menunjukkan bahwa model pembelajaran Student Facilitator and Explaining dapat meningkatkan motivasi belajar siswa. Dapat dilihat dari pra siklus ke siklus I maupun dari siklus I ke siklus II selalu mengalami peningkatan motivasi belajar siswa setelah diterapkannya model pembelajaran Student Facilitator and explaining. Hasil tersebut didukung dengan penelitian Idzhar, A. (2016). "Peran Guru Dalam Meningkatkan Motivasi Belajar Siswa". Jurnal office, Vol.2 No.2 dan penelitian yang dilakukan oleh Aziz, A., Ashari, A., \& Maftukhin, A. (2015). Penerapan Model Pembelajaran Student Facilitator And Explaining Untuk Meningkatkan Minat Dan Motivasi Belajar Fisika Siswa Kelas X SMA Negeri 10 Purworejo Tahun Ajaran 2013/2014. Radiasi: Jurnal Berkala Pendidikan Fisika, Vol 6 No, 2.

\section{Hasil Belajar Siswa}

Model pembelajaran Student facilitator and Explaining adalah salah satu model pembelajaran yang dirancang agar siswa mampu menyampaikan ide atau gagasan yang mereka miliki kepada temantemannya. Bukan hanya itu, model ini juga dirancang agar mampu meningkatkan motivasi dan aktifitas siswa dalam proses belajar mengajar sehingga dapat berpengaruh pada hasil belajar yang diperoleh siswa model ini juga dirancang dengan tujuan untuk penguasaan materi.

Pelaksanaan tindakan dimulai dari siklus I yang dilaksanakan sebanyak dua kali pertemuan, dimana evaluasi diberikan pada saat pertemuan kedua dengan memberikan tes hasil belajar yang berupa soal pilihan ganda untuk mengetahui sejauh mana tingkat pemahaman dan perkembangan hasil belajar siswa setelah penerapan model pembelajaran Student facilitator and Explaining. Adapun tes hasil belajar pada siklus I dengan persentase ketuntasan sebesar 55,55\% dengan rata-rata $75,92 \%$. Nilai tertinggi 90 dan nilai terendah 50 dengan jumlah siswa sebanyak 27 orang. Siswa yang tuntas belajar sebanyak 15 orang sedangkan siswa yang tidak tuntas sebanyak 12 orang. Hasil tes siklus I ini menunjukan bahwa penerapan model pembelajaran Student Facilitator and Explaining dapat meningkatkan hasil belajar siswa. Sebelum dilakukannya tindakan, hasil belajar siswa masih banyak yang tidak mencapai KKM, tetapi setelah dilaksanakannya tindakan dengan menerapkan model pembelajaran Student facilitator and Explaining maka hasil belajar siswa meningkat 4,07\%. Hasil tersebut didukung dengan penelitian Dita Wuri Andari(2013) bahwa penerapan model pembelajaran Student Facilitator and Explaining (SFAE) dapat meningkatkan hasil belajar siswa pada mata pelajaran FISIKA kelas VIII SMP Nurul Islam.

Pelaksanaan tindakan siklus II dilakukan selama dua kali pertemuan dimana evaluasi dilakukan di pertemuan kedua dengan memberikan tes hasil belajar yang bertujuan untuk mengetahui sejauh mana tingkatan pemahaman dan peningkatan hasil belajar siswa dari siklus I. Adapun perolehan tes hasil belajar siklus II dengan persentase ketuntasan sebesar 81,48\% dengan nilai ratarata sebesar 87,04 . Adapun siswa yang tuntas belajarnya sebanyak 22 orang dan siswa yang tidak tuntas sebanyak 5 orang. Hasil yang diperoleh siswa pada siklus II ini sudah mencapai indikator ketuntasan secara klasikal yakni $80 \%$ sedangkan yang diperoleh mencapai $81,48 \%$. Artinya penelitian sudah dikatakan berhasil sehingga penelitian ini tidak dilanjutkan lagi pada siklus berikutnya karena hasil belajar Al-Qur'an Hadits di kelas V.B telah meningkat melalui penerapan model pembelajaran Student Facilitator and Explaining. Hasil tersebut didukung dengan peneltian Putu Bayu Aji (2017) bahwa penerapan model pembelajaran Student Facilitator And Explaining (SFAE) dapat meningkatkan hasil belajar siswa sebagaimana yang dijelaskan dalam hasil penelitiannya dan I Gede Parsa Ananta (2019) bahwa penerapan model pembelajaran Student Facilitator And Explaining (SFAE) dapat meningkatkan hasil belajar siswa sebagaimana yang telah dijelaskan dalam hasil penelitiannya.

Berdasarkan uraian diatas dapat disimpulkan bahwa model pembelajaran Student Facilitator and Explaining dapat meningkatkan motivasi dan hasil belajar siswa. Model pembelajaran ini dapat 
dijadikan sebagai salah satu alternatif untuk menumbuhkan motivasi belajar siswa karena didalam model ini menuntut siswa untuk memiliki rasa bersaing yang tinggi didalam proses pembelajaran dan mendorong siswa untuk lebih mudah memahami materi pembelajaran. Selain itu, proses pembelajaran akan berlangsung dengan baik apabila dikolaborasikan dengan penggunaan media didalam proses pembelajarannya. Jika proses pembelajaran sudah mampu berjalan dengan baik, maka hasil belajarnya juga pasti akan baik pula.

\section{SIMPULAN DAN SARAN}

Berdasarkan hasil penelitian dan pembahasan yang telah diuraikan di atas dapat ditarik kesimpulan bahwa model pembelajaran Student Facilitator And Explaining dapat meningkatkan motivasi belajar siswa di MIN 1 Kendari. Dapat dilihat pada hasil perolehan angket motivasi belajar yang diberikan pada siswa kelas V.B MIN 1 Kendari. Pada kegiatan pra siklus, motivasi belajar siswa mencapai 70,37\% dengan kategori cukup termotivasi. Kemudian setelah tindakan siklus I, motivasi belajar siswa sebesar $85,19 \%$ dengan kategori sangat termotivasi. Kemudian, pada tindakan siklus II motivasi belajar siswa sebesar 88,88\% dengan kategori sangat termotivasi. Selain itu, model pembelajaran Student Facilitator and Explaining dapat menigkatkan hasil belajar siswa di MIN 1 Kendari. Hal ini dapat dilihat pada hasil tes yang diperoleh siswa pada pra siklus atau sebelum dilakukannya tindakan, hasil belajar siswa sebesar 48,14\% dengan rata-rata 71,85 kemudian setelah dilakukannya tindakan siklus I hasil belajar siswa meningkat menjadi 55,55\% dengan rata-rata sebesar 75,92 dan pada tindakan siklus II, hasil belajar siswa meningkat menjadi $81,48 \%$ dengan rata-rata 87,04 . Adapun peningkatan hasil belajar dari siklus I ke siklus II sebesar $40 \%$ dan persentase peningkatan dari pra siklus ke siklus II sebesar $61,54 \%$. Limitasi dalam penelitian ini yaitu pada waktu penelitian. Karena jadwal mata pelajaran Al-qur'an Hadits di MIN 1 Kendari setiap minggunya hanya $1 \mathrm{x}$ dalam seminggu, sehingga membuat waktu penelitian menjadi lebih lama. Dalam penelitian ini menghabiskan waktu selama 2 bulan.

\section{UCAPAN TERIMAKASIH}

Terima kasih kepada kedua orang tua yang selalu memberikan dukungan dan doa kepada penulis. Kepada dosen pembimbing, ibu Raehang S.Ag.,M.Pd.I., yang telah membimbing dan membina penulis sehingga dapat menyelesaikan karya tulis ini pada waktu yang telah ditentukan dan tak lupa pula ucapan terima kasih kepada dosen penguji bapak H. Pairin. M.A dan bapak Sufiani M.Pd.I., yang senantiasa memberikan masukkan kepada penulis.

\section{DAFTAR RUJUKAN}

Ananta, I. G. P. (1858). Penerapan Model Pembelajaran Kooperatif Tipe Student Fasilitator And Explaning Untuk Pendidikan Agama Hindu. 3.

Aziz, A. (2015). Penerapan Model Pembelajaran Student Facilitator and Explaining untuk Meningkatkan Minat dan Motivasi Belajar Fisika Siswa Kelas X SMA Negeri 10 Purworejo Tahun Pelajaran 2013/2014. Radiasi: Jurnal Berkala Pendidikan Fisika, 6(1), 118-121.

Akib, Z. (2001). Penelitian Tindakan Untuk SMP, SMA. Dan SMK (Bandung). Alam Wijaya.

Akib, Z. (2011). Penelitian Tindakan Untuk Guru SD, SLB. Dan TK. Alam Wijaya.

Aji, putu bayu. (2014). Pengaruh Model Pembelajaran Kooperati Tipe Student Facilitator And Explaining (SFAE) Dengan Pendekatan Saintifik Terhadap Hasil Belajar Fisika. Jurnal Pijar MIPA, 2 No 1. 
La Anse \& Ilham. M. (2018). The Implementation of Cooperative Learning (Numbered Head Together) to Boost Students' Learning Outcome in Social Studies Subject. IOP Conference Series: Earth and Environmental Science. IOP Publishing.

Putu, B. (2014) "Pengaruh Model Pembelajaran Kooperati Tipe Student Facilitator And Explaining (SFAE) Dengan Pendekatan Saintifik Terhadap Hasil Belajar Fisika"' Jurnal Pijar MIPA, Vol.2.No.1, Bali.

Rulli Marcalena. (2014). Penggunaan Model Pembelajaran Student Facilitator And Explaining (SFAE) Berbantu Mind Mapping Untuk Meningkatkan Komunikasi Lisan Dan Otivasi Belajar Siswa Smp Negeri 1 Mojotegah Tahun Pelajaran 2013/2014. Universitas muhammadiyah Purworejo.

Shoimin, A. (2014). 68 Model Pembelajaran Inovatif Dalam Kurikulum 2013. Arruz Media.

Sugiyono. (2009). Metode Penelitian Pendidikan Pendekatan Kuantitati, Kualitatof, dan R\&D. Alfabeta.

Sudijono, A. (2004). Pengantar Statistik Pendidikan. PT. Raja Graindo Persada.

UU RI, No. 20 Tahun 2003 Tentang system pendidikan Nasional. (2003). Direktorat Jendral Pendidikan Islam Agama RI.

Widayani P, Putra I, G. N. (2014). pengaruh student facilitator and explaining berbantu peta konsep terhadap hasil belajar PKN kelas V SD Gugus Igusti Ngurah Rai. Jurnal Mimbar PGSD Uniersitas Pendidikan Ganesa, Vol 2. No.1 